\title{
A Inocência e o Vício: Du Coté De Chez Proust*
}

JURANDIR FREIRE COSTA**

Em 1909, Proust acrescenta a Contre Sainte-Beuve um tema estranho à crítica literária, objeto daquele trabalho. O Narrador, encontrando o Sr. de Guercy numa recepção dos Guermantes, é "surpreendido pela revelação de que o infeliz aristocrata não só parece uma mulher mas é uma mulher, visto que pertence à raça dos homens que amam outros homens". ${ }^{1}$ Em seguida, diz seu biógrafo, Painter, ele escreveria a mais longa frase de sua vida, "como se não ousasse parar, pois se parasse seria para sempre. No que a frase continha de angustiada crueldade, magoada piedade e trágica beleza se encontravam, respectivamente, a acusação de Proust, sua defesa e sua confissão de homossexualismo." 2

A frase fazia parte de um ensaio sobre o "homossexualismo", que deveria ter sido publicado no ano anterior. Motivado pelo escândalo do processo penal de Phillip von Eulenburg, nobre diplomata e amigo do kaiser Guilherme II, da Alemanha, Proust decidira escrever algo sobre o assunto. Entretanto, dis-

* Este trabalho é parte da obra A inocência e o vício - Ensaios sobre o homoerotismo, do mesmo autor, publicado por Relume-Dumará Editores, Rio de Janeiro, 1992.

** Professor adjunto do Departamento de Políticas e Instituições de Saúde do Instituto de Medicina Social/UERJ.

1 PAINTER, George D. Marcel Proust, Rio, Guanabara, 1990, p. 484.

2 Ibid. 
suadido pelo amigo Robert Dreyfus, adiou o projeto, retomando-o, com alterações, no ensaio Contra Sainte-Beuve, sob o título "A raça maldita".

Em 1921, voltou a abordar a questão, do modo como apareceu na redação final de Sodoma e Gomorra I. Proust, por ocasião da edição desse livro, estava temeroso. Acreditava que a longa dissertação sobre a inclinação sexual do barão de Charlus, personagem que viera a substituir o Sr. de Guercy, provocasse celeuma. O teor das críticas, no entanto, dissipou esta apreensão. Jacques Rivière, da Gallimard, editora de Proust, disse: "Eu saboreio, entre outras coisas (é ruim de dizer, você não o repetirá), uma espécie de vingança ao ler as páginas terríveis (e tornadas ainda mais terríveis por sua eqüidade mesma), em que você descreveu a raça do Sodomitas. Eu necessitava desta espécie de descongestão que me dão estas páginas. Sem me abalar, escutei muito freqüentemente ao meu redor falsearem a noção de amor, e por isso experimento um alívio delicioso escutando alguém, tão sadio e tão felizmente equilibrado como você, tratando do assunto." ${ }^{3}$ Roger Allard, da mesma Gallimard, afirmou: "Estas páginas de ardente eloqüência, essa poesia áspera e nobre, quebram o feitiço estético da inversão sexual, que há muito tempo vem escravizando as artes e a literatura." ${ }^{4}$ Finalmente, Gide, relatando um encontro com Proust, anotava em seu diário de 15 de maio de 1921: "Ainda esta noite, só falamos de uranismo; ele diz reprovar-se pela indecisão que o levou, para nutrir a parte heterossexual de seu livro, a transpor para a l'ombre de jeunes filles tudo o que suas lembranças homossexuais tinham de gracioso, terno e charmant, de modo que só lhe restou para Sodoma o grotesco e o abjeto." ${ }^{5}$ Em 2 de dezembro do mesmo ano, Gide voltava ao tema: "Li as últimas páginas de Proust (...), de início, com um sobressalto de indignação. Conhecendo o que ele pensa, o que ele é, é difícil para mim ver nisto algo além de um fingimento, de um desejo de se proteger, de uma camuflagem, que não podia ser mais hábil, pois ninguém pode tirar vantagem em denunciá-la. Mais do que isso: esta ofensa à verdade corre o risco de agradar a todos: aos heterossexuais, cujas prevenções ela justifica e cujas repugnâncias, lisonjeia; aos outros que tirarão proveito do álibi e da pouca semelhança com aqueles que ele retrata. Em suma, a covardia geral ajudando, eu não conheço nenhum escrito que, mais que Sodoma de Proust, seja capaz de enterrar a opinião pública no erro." 6

3 Cit. por COMPAGNON, Antoine, in: PROUST, M., Sodome et Gomorrhe, Paris, Gallimard, 1989, p. XXXI.

4 Ibid.

5 GIDE, A. Journal, 1889-1939, Paris, Gallimard, 1948, p. 694.

6 Ibid, p.705. 
Gide com certeza, tinha em mente a conversa tida meses antes com Proust. Sobre ela, escrevera em 14 de maio de 1921: "Eu the dou Corydon, do qual ele me promete não falar com ninguém; e como lhe digo algumas coisas de minhas Memórias: 'Você pode contar tudo', gritou ele mas com a condição de jamais dizer Je. O que não é meu gênero." "Proust e Gide, com a força e densidade de seus textos, indubitavelmente ajudaram a conferir substância imaginária à crença de que os homens dividem-se intuitiva e naturalmente em "homossexuais" e "heterossexuais". Sem eles, a idéia hoje quase indiscutível para a maioria de todos nós, de que existe um tipo humano homossexual, com características próprias e irredutíveis a outros homens, provavelmente perderia grande parte de seu poder persuasivo. A genialidade do primeiro e a equivocada e comovente honestidade intelectual do segundo deram verossimilhança humana à descarnada ficção médica, sexológica e jurídica do sodomita, uranista, saturniano, pederasta, invertido, perverso e, por fim, "homossexual". Tematizando obsessivamente a sexualidade homoerótica oitocentista, problema cultural e pessoal comum a ambos, inventaram o vocabulário com que nos habituamos a reconhecer, designar ou descrever a "pretensa realidade psicologica" de todos os sujeitos inclinados aos "amores masculinos", conforme a expressão de Peter Gay. ${ }^{8}$

Gide, no entanto, pensava alcançar a verdade quando confessava, a despeito do pudor, suas tendências e experiências homoeróticas. Proust, não. Dissimulava deliberada ou inconscientemente o que o outro se atrevia a exibir. Porém, a dissimulação não se devia apenas ao medo da reprovação do Faubourg. Se, de fato, ele temia a opinião do grand monde de Saint-Germain, simultaneamente odiado e idolatrado, através do receio dizia coisas que Gide não soube ouvir. Quando disse que se podia contar tudo mas nunca dizer $J e$, era porta-voz das "intermitências do coração", peça-chave de sua redescoberta do tempo perdido. Recusando-se a falar do sexo em primeira pessoa, exprimia sua ambigüidade ética, mas também a conviç̧ão tardiamente conquistada de que um nome próprio é a morada de vários "Eus". Como apontou magistralmente Deleuze, o homoerotismo em Proust foi sempre, ao mesmo tempo, plaidoyer pela inocência do sexo e pedido de perdão pelo vício. Cada um destes desejos é suporte de um Je. Ao apresentar-se como mestre da verdade sobre o amor, ele oculta necessariamente, ao olhar do outro, desejos e "Eus" indizíveis ou não ditos. Para Gide, nunca dizer Je era mentir; para Proust, era mentir e

7 Ibid, p. 692.

8 GAY, P. A paixão terna. A experiência burguesa da rainha Vitória a Freud. São Paulo, Companhia das Letras, 1990. 
afirmar, em cada mentira, que para cada Eu que fala há pelo menos um outro Eu que é obrigado a calar.

\section{As intermitências do coração}

O trecho de Sodoma e Gomorra onde o Narrador descobre o homoerotismo do barão de Charlus é uma obra-prima de ambigüidade e clarividência inconscientes. Nele, Proust resume o ethos de uma época e as indecisões de uma alma a procura de si mesma. Proust era um homem entre dois mundos. De um lado, estavam as ilusões da infância e juventude, ou seja, o encantamento por Combray e pelo Faubourg Saint-German; de outro, a maturidade artística e a decepção com as convenções burguesas e aristocráticas. A busca do tempo perdido é o sintoma deste conflito insolúvel. O tempo social de Proust era um tempo em transformação. A aristocracia representava o passado, o apego à tradição, ao nome e aos rituais de convivência exclusiva dos que se achavam os "melhores"; a burguesia, em oposição, representava o anseio pela competição, mobilidade e individualidade e pelo culto à intimidade da vida privada $\mathrm{e}$ aos valores da pequena família nuclear. ${ }^{9}$ A exemplo de tantos outros burgueses de então, Proust vivia a tensão espiritual dos que já não sabiam o que devia mudar e o que devia continuar.

Walter Bagehot, um grande burguês e pequeno intelectual britânico, escreveu: "O homem moderno precisa que lhe digam o que pensar - em poucas palavras, sem dúvida - , mas precisa que lhe digam." ${ }^{10}$ Proust, entretanto, ao desencantar-se com o mundo dos Guermantes, depois da Caso Dreyfus, percebeu que ninguém nem nada poderia dar-lhe a última palavra sobre o mundo e os homens. "O Caso Dreyfus", diz Painter, "quebrara o encantamento do caminho de Guermantes. Proust via seus amigos despojados da aura de poesia com que ele próprio os revestira: uma duquesa não passava de uma mulher usando tiara; um duque era apenas um burguês com um grau exagerado de altivez ou afabilidade. Proust compreendeu que ao entrar no mundo cruel e vazio dos Guermantes, e ao buscar nele algo superior a si mesmo, cometera um pecado e um ato absurdo." 11 Isto é, percebeu que podia criar uma visão do

9 WEBER, E. França fin-de-siècle. São Paulo, Companhia das Letras, 1988; PERROT, M. "Funções da familia", in: História da Vida Privada, op. cit. pp. 105-121, 1991; MARTINFUGIER, A. "Os ritos da vida privada burguesa", in: História da Vida Privada, op. cit., pp. 193-203, 1991; GAY, P. A paixão terna, op. cit.

10 GAY, P. op. cit., p. 47.

11 PAINTER, G. D. op. cit., p. 254. 
mundo e dos homens, cuja medida era sua fantasia. A partir de então, entendeu que o fundamento de nossas crenças não tem outra garantia a não ser as infidelidades do desejo ou as "intermitências do coração". Viu que o Je, como observou Rorty ${ }^{12}$ a seu respeito, é apenas um tecido de contingências, e que a vida do Faubourg, para ele idêntica ao mundo ideal, era só mais um caricato baile de máscaras, como notou Arendt. ${ }^{13}$

Esta foi a "dor da idéia nova", como dizia Bagehot, que o surpreendeu na busca do tempo perdido. Era inútil procurar nos caminhos do Eu ou nos caminhos do mundo o recanto tranqüilo onde um verdadeiro sujeito reconhecesse e tomasse posse do verdadeiro amor e do verdadeiro bem. O chez soi, como o chez Swann, não era um sólido edifício de estórias e memórias perenes do que verdadeiramente é ou tinha sido; era um teatro de espectros e sombras, um novo salão, que, em sua própria imagem, vivia povoado de "romances inconscientes". ${ }^{14}$ Tendo uma aguda consciência disto, afirmou certa vez: "A qualquer momento que a considerarmos, nossa alma total tem somente um valor quase fictício, malgrado o numeroso balanço de suas riquezas, pois ora umas ora outras são indisponíveis, quer se trate, aliás, de riquezas afetivas ou daquelas da imaginação, e, para mim, por exemplo, tanto quanto o nome de Guermantes, quanto aquelas mais graves, da lembrança verdadeira de minha avó. Pois, aos distúrbios da memória estão ligadas as intermitências docoração. Ésem dúvida a existência de nosso corpo, para nós semelhante a um vaso em que nossa espiritualidade estaria encerrada, que nos induz a supor que todos nossos bens interiores, nossas alegrias passadas, todas nossas dores estão perpetuamente em nossa posse. Talvez também seja inexato acreditar que elas se evadem ou retornam. De qualquer modo, se elas permanecem em nós, estão, na maioria do tempo, em um domínio desconhecido onde não têm serventia alguma e onde mesmo as mais usuais estão recalcadas por lembranças de ordem diferente e que excluem toda simultaneidade com elas na consciência. Mas, se o quadro de sensações com que estão conservadas é reapreendido (ressaisi), elas têm, por sua vez, o mesmo poder de expulsar o que lhes é incompatível, de, sozinha, instalar em nós o ego que as viveu. (...) $\mathrm{O}$ ego que eu era então, e que havia por tanto tempo desaparecido, estava novamente tão perto de mim que me parecia ainda escutar as palavras que tinham imediatamente precedido e que no entanto

12 RORTY, R. Contingency, Irony, and solidarity, Cambridge, Cambridge University Press, 1989.

13 ARENDT, H., As origens do totalitarismo - Anti-semitismo, instrumento de poder. Rio, Editora Documentário, 1979.

14 PROUST, M., op. cit., p. 531. 
não eram mais que um sonho, como um homem mal acordado acredita perceber bem próximo dele os ruídos do sonho que se evade."15

Revisitando o passado para dar sentido ao presente, compreendeu que não existe nenhum apoio extramundano e extra-humano para a verdade de nossas crenças no sexo e no amor. Não existem memórias de um sujeito; existem sujeitos de memórias, que são independentes de quem se julga seus autores. Não existe um mundo mental sempre lá, contínuo, igual a si mesmo e juiz de nossos erros e acertos sobre o que enunciamos sobre ele; existem imagens e narrativas deste mundo, que espelham nossas aspirações ao prazer ou à dor. Enfim, não existe outra verdade da lembrança, exceto aquelas das "intermitências do coração". Quando disse a Gide "jamais diga Eu", dizia que a mentira era a contraface da verdade, dependendo do "coração" que mente e do coração a quem ela é dita.

Gide, sabemos, afirmou num dado momento: "Ie ne suis jamais, je deviéns; je deviéns celui que je crois que je suis." Porém, assim falando, inspirava-se na verdade de sua consciência burguesa e protestante. Ora, para esta consciência havia um ponto em que o devenir do Je deveria estancar, pondo um fim à dúvida sobre si. Este ponto era a autenticidade. Era o ponto onde $\mathrm{o}$ $J e$ abandonava a dissimulação e, através da revelação do verdadeiro desejo, expunha-se ao outro, na sua suposta capacidade de entender, amar e perdoar. Nesta crença, Gide testemunhava sua confiança na onisciência e bondade divinas. Ela foi a marca indelével da retidão calvinista de seu caráter e sensibilizou a todos quantos o conheceram ou tiveram contato com sua obra. Não é à toa que um espírito descrente, cínico e histriônico, com Oscar Wilde, desconfiava dela e sentia-se instigado a destruí-la. Quando Wilde encontrou Gide em Paris e procurou seduzi-lo intelectualmente com suas frases de efeito, disse depois a Douglas, seu amante, que ele era um "protestante francês, a pior espécie, salvo, é claro, o protestante irlandês", aludindo, desta maneira, às suas origens religiosas. ${ }^{16}$ "Queixou-se, ainda, de que os lábios de Gide eram demasiado retilíneos, lábios de alguém que jamais mentiu." ${ }^{17} \mathrm{E}$, por último, concluiu: "Preciso ensiná-lo a mentir, para que seus lábios sejam belos e curvos como os de uma máscara antiga." 18

$\mathrm{O}$ destino de Proust foi outro. $\mathrm{O}$ acaso nunca deixou que encontrasse face a face esse Deus magnânimo e compassivo, não obstante a severidade. Seus

15 PROUST, M., op. cit., pp. 153-154.

16 ELMAM, R., Oscar Wilde, São Paulo, Companhia das Letras, 1989, p. 313.

17 Ibid.

18 Ibid. 
deuses ou outros eram o mundo dos Guermantes e o amor materno, com sua estrita moralidade burguesa. Ambos pareciam ignorar o perdão e só reconhecer um Je e um desejo de Marcel Proust, o de pertencer-lhes de corpo e alma e o de duvidar eternamente da veracidade do amor recebido. Com a morte da mãe e a queda de Faubourg, Proust liberou-se da coerção real, mas não da dívida ética que contraíra imaginariamente com os dois. A encarnação do Bem, fundida na aristocracia e na figura materna, não mais existia, mas deixou como herança o fantasma da culpa e da necessidade de punição. Deste fantasma, Proust extraiu a matéria de sua ficção do Narrador e da prodigiosa invenção da inocência e do vício da "inversão", uma e outro feitos de medo e dissimulação. Recriando as metáforas da inocência e do vício homoeróticos, livremente disponíveis no imaginário social de seu tempo, legou-nos a fantasiosa idéia da "natureza do invertido", cuja extraordinária sedução estética sobrevive até hoje.

\section{A linguagem do vício}

Proust vivia um tempo sem compaixão. A moralidade do século XIX, pano de fundo de sua ética erótica, não perdoava os indecisos. Exigia, sobretudo das elites, que tomassem partido no conflito ideológico que opunha as duas classes dominantes, a aristocracia e a burguesia. A aristocracia francesa fin-desiècle havia perdido todo poder político, econômico e social. Economicamente, limitava-se à especulação e ao arrendamento de terras; politicamente, a ocupar postos na hierarquia militar; socialmente, a encenar uma supremacia inexistente, simulando gosto, sensibilidade e liberalidade diante do novo e do exótico, desde que, evidentemente, não dissesse respeito às questões políticas. A alta burguesia, por sua vez, dispunha de poder político-econômico mas carecia de distinção social. Os salões mundanos traduziam esta rivalidade nas alianças e lutas estratégicas entre o dinheiro de uns e os brasões de outros. Ninguém podia permanecer neutro no combate de valores. O que estava em jogo era o controle dos corpos, sexos e mentalidades da massa de súditos ou subordinados, apelidados de indivíduos ou citoyens. Para exorcizar o fantasma da queda de prestígio, ou o supremo inimigo da época, a democratização dos direitos políticos e dos costumes sociais, todas as armas eram válidas. Os bem-nascidos queriam continuar monopolizando os sinais de superioridade de casta; os filhos da Revolução queriam transformar a casta em "raça" e, todos juntos, aliavam-se para excluir da sociedade dos "homens bons" os condenados da terra e os explorados das cidades.

Em 1890, na revista Le Fin de Siècle, o editor escrevia: "Nada de classes, títulos ou raças. Tudo é misturado, confundido. indistinto e reembaralhado, 
numa visão caleidoscópia." ${ }^{19}$ No fin-de-siècle, ecoava o visconde d'Avenel, discutindo sobre os transportes públicos, "duquesas e milionários se acotovelam com cozinheiras e funcionários". ${ }^{20}$ Esta retórica grandiloqüente e sensacionalista, bem ao gosto de uma imprensa embriagada com o aumento de seu poder social, soava às elites como um alarme. No Faubourg ela evocava a Comuna, as cabeças cortadas e o ostracismo insuportável vivido sob a República. Nobres e burgueses, circulando em salões ociosos, exauriam-se assim em disputas intermináveis para restabelecer a ordem e a hierarquia, ameaçadas pelo caos da proletarização e do aburguesamento generalizado. Quando Proust, comentando o prosaico ar burguês do duque de Bouillon, afirmou que "um grand seigneur do tempo de Luis Felipe é menos diferente de um burguês do tempo de Luis Felipe que de um grand seigneur do tempo de Luis XV", observou, de modo ameno, o que para os frequentadores dos salões era uma questão incendiária. ${ }^{21}$ A guerra da distinção era torpe: violência odiosa dos mais fortes, servilismo obsceno dos mais fracos. Mme. de Guermantes diz, respondendo a certa solicitação do marido: "Ah, não, isto não! Penso que você está me gozando. Eu nem sei porque cargas d'água conheço o nome dessa anta. Isto é a borra da sociedade! É como se você me pedisse para que eu lhe apresentasse à minha costureira. E, olhe lá, não é verdade, pois minha costureira é charmante." 22 O episódio em que o barão de Charlus humilha cruclmente Mme. Saint-Euverte é em tudo semelhante ao anterior. Proust, no entanto, constatando que a ofendida aceita passivamente a humilhação $\mathrm{c}$ reage como quem se "ajoelha diante de seu senhor", comenta: "Infelizmente, no mundo, como no mundo político, as vítimas são tão covardes que não se pode ficar muito tempo zangado com os carrascos." 23 O mesmo barão de Charlus, em outra passagem, ilustra a prepotência dos que se achavam acima dos demais mortais. Dizia, a propósito das famílias nobres, que, na França, elas eram quando muito onze, e acrescentava: "Quanto a todos esses petits messieurs que se chamam marquês de Cambremerde [aludindo aos Cambremer] ou Fatefairefiche [corruptela homofônica da expressão grosseira "va te faire fiche", equivalente mais pesado da expressão "vai te catar" ou "vai te danar"], não existe nenhuma diferença entre eles e o último dos franguinhos (piou piou) de seu regimento. Que você vá fazer xixi na casa da condessa Cocô, ou cocô na

19 WEBER, E., op. cit., p. 20.

20 Ibid, p. 97.

21 PROUST, M., op. cit., p. 81 .

22 Ibid, p. 122.

23 PROUST, M., op. cit., p. 100. 
casa da baronesa Xixi, é a mesma coisa, você comprometeu sua reputação e usou um pano de chão cagado (breneux) como papel higiênico. O que é sujo."24

O Faubourg era o retrato dos grupos sociais sem função ou sentido históricos. ${ }^{25}$ Nele, o estilo de vida era marcado pela monotonia das pequenas intrigas ridículas e previsíveis. Para vencer o tédio e mostrar aos burgueses a excelência do viver aristocrático, as maittresses dos salões disputavam ferozmente a presença de celebridades da cultura e das artes, ou de obscuros exemplares de vidas exóticas. Esta elite fazia do cinismo e da manipulação da vaidade tola dos parvenus, remédio para seu cansaço mundano e sua inutilidade social. Incapaz de produzir valores minimamente aceitáveis para sua época, comprazia-se em afetar uma largueza de mentalidade que nada mais era do que um sintoma do culto ao "très puissant Dieu Je-Men-Fou", como dizia Brichot, fazendo Mme. Verdurin morrer de rir. ${ }^{26}$ Por indiferença e faltade escrúpulo, e não por tolerância, o Faubourg admitiu judeus e "homossexuais" em seu meio. ${ }^{27}$ Mas o interesse pelos novos eleitos só se conservava enquanto o mistério de seus exotismos persistia; enquanto o segredo de suas "raças" ou de suas "psicologias" mantivesse acesa a conversação e a curiosidade dos rotos espíritos de seus habitués. ${ }^{28}$

Proust era perfeitamente ciente do papel ocupado pelo vicioso e pelo exótico na vida do Faubourg. Referindo-se à vã tentativa de Charlus em ocultar de seus hóspedes suas reais tendências sexuais, diz: "E, aliás, de qualquer maneira ele estaria errado, buscando calá-la [a inclinação sexual], pois não existe nenhum vício que não encontre no grand monde apoios complacentes..." ${ }^{29}$ Em outro trecho, referindo-se ao mesmo Charlus, escreveu: "Nesse primeiro período, tinha-se, então, terminado por achar M. de Charlus inteligente, não obstante seu vício (ou o que se chama geralmente assim). Agora, sem que se dessem conta, era por causa desse vício que achavam-no mais inteligente que os outros. As máximas mais simples que, devidamente provocado por um universitário ou um escultor, $\mathrm{M}$. de Charlus enunciava sobre o amor, o ciúme, a beleza, por causa da experiência singular, secreta, refinada e monstruosa das quais ele as havia extraído, ganhavam, para os fiéis, o charme de estranhamento de que se reveste uma psicologia (...) em uma peça russa ou

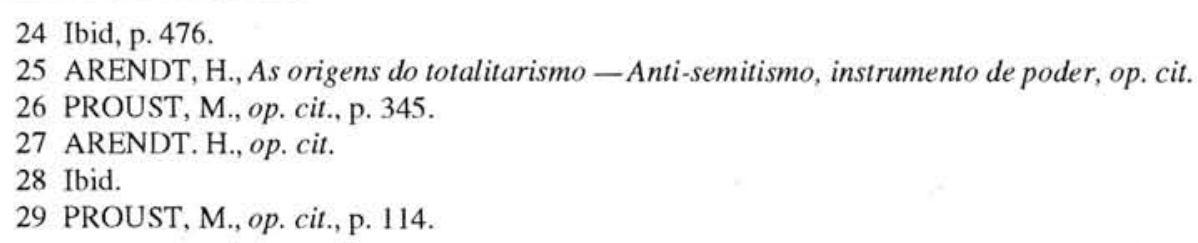


japonesa, desempenhada por artistas daqueles lugares." ${ }^{30}$ O Faubourg havia transformado o crime em vício para seu deleite. Porém os casos de Wilde e Eulenburg mostraram que o vício sem charme era implacavelmente massacrado. Sendo francês, meio judeu, burguês e acreditando-se "homossexual", ele agia como se tivesse ouvido o que Metternich dissera sobre a França: "A fraternidade como é praticada na França me levou a concluir que, se tivesse um irmão, deveria chamá-lo de primo." ${ }^{31}$ dissimulação, na busca do tempo perdido, tornou-se, assim, o primeiro mandamento da arte de falar de si. Dizendo o que achava que era, sem se nomear, Proust tentava sobreviver no único universo que conhecia. Construiu uma imagem do homoerotismo que obedeceu aos cânones da vida em salão. Ou seja, apresentava o "invertido" mascarado de aristocrata torpe ou de burguês arrivista, para desmoralizar o Faubourg, e aceitava simultaneamente as premissas morais que repudiava, associando a "inversão" ao mundo dos homens ocos. Suas personagens eram vítimas ou algozes, conforme o ângulo visto, mas de qualquer perspectiva continuavam sitiados pelo ódio, o ressentimento e a humilhação.

Quando Proust buscava absolver-se da culpa por seus desejos homoeróticos, inocentando a inversão, (preferia este termo ao termo homossexual, que julgava "trop germanique et pédant"), ${ }^{32}$ repetia os jargões naturalistas da época, os únicos capazes de serem aceitos sem levantar suspeitas. A inversão, dizia ele, era uma tara, uma doença; a qualidade de uma raça; um dado da hereditariedade ou o produto de um acaso infeliz na evolução natural. ${ }^{33} \mathrm{O}$ substrato do homoerotismo que descreve está próximo das generalidades médico-legais, psiquiátricas, sexológicas ou jurídicas, correntes no séc. XIX. Todas estas, de uma ou outra maneira, eram ramos das ideologias evolucionistas, em especial das teorias da degenerescência, verdadeiro espantalho cultural da burguesia oitocentista. ${ }^{34} \mathrm{Na}$ ciência, pensava Proust, estava o aval da inocência. Estava a verdade que permitia redimir o homoerotismo, sem devolver sua sexualidade à sarjeta ou ao crime. As freqüentes alusões a Oscar Wilde comprovam esta preocupação. Comentando a tagarelice e o histrionismo de Wilde, que fizeram-no acreditar na possibilidade teatral de transformar "sua vida em obra de arte", subestimando a truculência da hipócrita burguesia inglesa, disse: "Wilde que, depois de afirmar que a maior dor que experimentara

30 Ibid, p. 429.

31 WEBER, E., op. cit., p. 172.

32 Ver COMPAGNON, in Proust, op. cit. p. XV.

33 Ibid, pp.29, 63-64, 91, 94, 95, 192, 300, 343, 344, 356, 450, 454, etc.

34 WEBER, E., op.cit., PERROT, M., op.cit, 1991. 
fora a morte de Lucien de Rubempré [herói de Balzac e objeto da paixão homoerótica de Vautrin] não tardou a aprender, durante seu processo, que existem dores ainda mais verdadeiras." 35

Assim, a exemplo de Gide, fez do vício um fato natural e do sujeito homoeroticamente inclinado, um exemplar de uma raça, com qualidades especiais. Só que, ao contrário de Gide, recuou diante do álibi do instinto. Gide divinizou a natureza e converteu sua idealizada "pederastia" numa bênção natural, pervertida pela "decadente maioria heterossexual" ${ }^{36}$ Proust, inversamente, alinhou o homoerotismo na fileira dos "erros da natureza", dos "desequilíbrios nervosos", das "taras doentias" etc. Como assinalaram Rivers ${ }^{37} \mathrm{e}$ Alter, ${ }^{38}$ a inversão proustiana deixou de ser vício ou crime para ser desvio ou anomalia. Ou seja, o Narrador desapontava o voyeurismo do Faubourg, quebrando a magia de seus fetiches; em troca, entregava o homoerotismo à tecnocracia médico-científica que a burguesia ascendente pusera a seu serviço.

Temos boas razões para supor que Proust acreditava menos na "naturalidade da inversão" do que deixou transparecer em seus livros. Em 1897, ao ler a Psychopathia Sexualis de Kraft-Ebing, pai espiritual das ideologias sexológicas dos séculos XIX e XX, comentou com seu amigo Paul Morand: "Parece que agora até o vício se tornou uma ciência exata." 39 Portanto, em Sodoma e Gomorra, como nos escritos anteriores, quando fez sua a linguagem que antes criticara, revelava duas coisas: primeiro, que não tinha coragem de mostrar a inocência como virtude, verdadeiro antônimo ético do vício, por receio de tornar-se um pária, ou um criminoso; segundo, que não dispunha de outra linguagem capaz de inocentar sua sexualidade, a não ser o vocabulário médico-científico de sua época. Usou, assim, as armas da ciência burguesa contra a aristocracia, salvando a respeitabilidade e sacrificando a ética. Proust não percebera, sufocado pelo Faubourg e por seu quarto de asmático, que nem todos os burgueses eram salonnards. Havia muitos - e estes foram os vencedores históricos - para quem pouco importavam os costumes aristocráticos, que, de

35 PAINTER, G.D., op. cit., p. 144.

36 COSTA, J.F., Impasses da ética naturalista: Gide e o homoerotismo. Conferência feita em São Paulo e Curitiba, no Seminário sobre "Ética", organizado pelo Departamento Cultural da Prefeitura de São Paulo, 1991, inédito.

37 RIVERS, J. E., "The Myth and Science of Homosexuality in A la recherche du temps perdu", in, Homosexualities and French Literature, Ed. George Stambolian e Elaine Marks, Ithaca and London, Cornell University Press, 1979, pp. 262-278.

38 ALTER, R., "Proust and the ideological reader", in:Salmagundi, nº 58-59, Fall 1982, Winter, 1983, pp. 347-358.

39 PAINTER, G. D. Marcel Proust, op. cit., p. 614. 
resto, eram vistos como idênticos à indecência, pecado ou causas de taras sociais. ${ }^{40}$ Havia um mundo ao lado do grand monde que acabara de nascer e criara um novo tipo "crime", o crime contra a natureza. Descrevendo o invertido como um "anormal", um praticante do "amor antifísico" e "anti-social", Proust subscrevia na íntegra o essencial dos preconceitos burgueses. Ia além, dava crédito e ajudava a fortalecer a idéia de que havia uma espécie humana com variedades e subvariedades, que surgia de um movimento no qual a natureza, conforme sua própria metáfora, parecia ter-se "momentaneamente industrializado". 41

É verdade: mesmo aí, sua intenção de inocentar o homoerotismo assumia, por vezes, um tom positivo e redentor. Ao comparar a atração mútua dos invertidos à beleza de certos fenômenos da vida vegetal e animal buscava mostrar o lado ensolarado da "inversão" e não seus desvãos escuros. Porém, a inocência, neste caso, era inconsciência e irresponsabilidade. $\mathrm{O}$ belo e $\mathrm{o}$ monstruoso eram produzidos pelas mesmas leis e mecanismos que secretavam poléns de orquídeas ou danças de abelhas. A inocência natural em Proust ou é auto-indulgente ou inconseqüente; jamais responsável. É marcada por uma culpa ou uma vergonha que retiram dos amores masculinos qualquer dimensão propriamente ética. Diferentemente do criminoso Vautrin, de Balzac, que Proust pretendia ter como modelo, Charlus e Jupien, instrumentos da natureza, levitam acima ou abaixo do Faubourg. Não dizem, como a personagem de Balzac, que numa sociedade viciosa o vício dos marginais pode ter a virtude da denúncia. Ao contrário, calam-se diante da opressão. Vivem seus amores como jogos proibidos, praticados às ocultas e só descobertos pelo voyeurismo do Narrador. As intermitências do coração, reduzidas a tropismos, aproximam a inocência sexual e a cumplicidade com o vício social.

Em Proust, a ética dos amores é posta de lado, em favor das coerções dos instintos. Convertido ao reino da necessidade, o homoerotismo masculino surge puro em algumas imagens, corrompido em outras, mas de qualquer modo, sempre eticamente indiferente. Melhor dito, na indiferença fingida, o Narrador, como Mme. Saint-Euverte, ajoelhava-se diante do Faubourg, negociando a honra em troca da aceitação.

40 HUNT, L. "Revolução Francesa e vida privada", in: História da vida privada, op. cit., pp. 21-23, 1991; HALL, C. "Sweet Home", in História da Vida Privada. Da revolução francesa à Primeira Guerra. Tomo 4, Coleção dirigida por Philippe Ariès e Georges Duby, São Paulo, Companhia das Letras, 1991, pp. 53-93.

41 PROUST, M., op. cit., p. 248. 
Sublimando o desejo num dado natural, Proust fabricou um Eden sem crime e castigo, mas onde o prazer e a felicidade eram indizíveis, pois desconheciam-se enquanto tais. No vício, entretanto, retorna o recalcado da inocência. Com mais culpa, mais força e mais dor, pois nele Proust se debate não apenas contra o espírito dos Guermantes, mas também contra o "espírito de Combray". Na recordação da infância passada, Combray trouxe de volta o discurso materno, assombrando-lhe a alma e liberando, de vez, sua imaginação. E é na reflexão sobre o vício que o artista excede seu tempo, criando uma "psicologia" do invertido, formada às custas de fantasmas, tanto mais verossímeis quanto feitos dos retalhos de sua vida. Este universo de criaturas fantasmáticas veio a ser, para as futuras gerações, a expressão da verdade sobre o homoerotismo. Proust impunha ao mundo o que o mundo lhe obrigara a criar. Individualizou cada dor, remorso, vergonha ou ressentimento nascidos de sua experiência homoer6tica, dando-lhes o rosto de uma personagem ou os "traços constitutivos" do pecado original da "raça das bichas". O vício, finalmente, era exposto e punido em público, como pediam o Faubourg e Combray. A mãe estava morta e os Guermantes eram uma reminiscência Marcel Proust, contudo, continuava a temê-los e reverenciá-los. Deu ao público de Sodoma o vício, escondendo a virtude dos seus amores "à l'ombre de jeunes filles en fleurs", como notara Gide.

Deste aspecto, Gide tinha razão. Proust ofendera a verdade. Mas não porque se recusara a crer no mito da autenticidade. A verdade foi ofendida quando o Narrador preferiu mostrar os amores masculinos como um fruto das paixões tristes. Dignificando artisticamente a linguagem do vício, Proust purificou-se do "pecado" e do "absurdo" de suas idolatrias mundanas e de suas tendências sexuais, mas negou aos outros, que não seus Outros, a visão dos amores que pôde viver em paz.

\section{A linguagem do vício}

Em 1907, um certo Henri van Blarenberghe matara a mãe e, em seguida, se suicidara. Proust, que havia conhecido rapidamente o jovem, foi solicitado a escrever um artigo sobre o crime. Uma testemunha havia escutado a Sra. Blarenberghe dizer antes de morrer: "Henri, que foi que você fez? Por que me fez isto, Henri?" 42 Proust escreveu o artigo que foi publicado com cortes em

42 PAINTER, G.D., op. cit., p. 405. 
Le Figaro. Num dado trecho era dito: "O que foi que você me fez? Se nos permitimos pensar nisto, perceberemos que talvez não haja mãe alguma, que ame verdadeiramente seu filho, que no último dia de sua vida, e provavelmente muito tempo antes, não lhe dirija esta censura. A verdade é que envelhecemos e matamos o coração que nos ama por causa das angústias que lhe causamos,da ternura inquieta que nele inspiramos e do estado de alarme constante que provocamos. Se pudéssemos ver, em um corpo amado, o lento processo de destruição levado a efeito por esse afeto angustiado, os olhos cansados, o cabelo que antes era indomavelmente negro e agora é derrotado como o resto e se torna branco (...) o espírito que sabe que nada resta a não ser o desespero, embora antes se alentasse incansavelmente com esperanças imbatíveis, a inata imortal alegria morta para sempre..." Terminava dizendo que, "se num momento de lucidez e equilíbrio mental como o de Van Blarenberghe ao ver a mãe sangrando até morrer, pudéssemos sentir todas essas coisas, também nos mataríamos com um tiro, como ele." 43

Já um ano antes, depois da morte da mãe, escrevia à Sra. Strauss a propósito da reabilitação de Dreyfus: "Nestes últimos dez anos, todos nós sofremos muitos desgostos, decepções e tormentos. E para nenhum de nós soará o momento em que nossos desgostos se converterão em alegrias, nossas decepções em realizações inesperadas, nossos tormentos em deliciosos triunfos. A cada dia eu estarei mais doente, cada vez sentirei mais falta dos seres queridos que perdi, e verei tudo aquilo que almejei na vida ficar cada vez mais inacessível. Porém, para Dreyfus e Picquart a vida tem sido providencial como um conto de fadas. A razão disso é que nossas desgraças se baseiam em verdades, sejam psicológicas, humanas ou emocionais, mas as desventuras deles foram causadas por simples erro. Benditas sejam as vítimas de erros, judiciais ou outras! Somente eles poderão obter uma espécie de ressarcimento e reparação." 44

Pouco tempo depois, Proust redigia "A raça das bichas" (La race des tantes), que serviu de molde à versão definitiva da inversão em Sodoma e Gomorra. Este texto, retomado várias vezes nos Cahiers, é um dos mais sombrios e caudalosos já escritos sobre o homoerotismo. Como notamos no início do trabalho, Proustescreve cerca de mil e quinhentas palavras numa única frase, onde a mais soberba imaginação mostra o esgarçamento de uma consciência presa ao desmentido inútil do próprio desejo. A citação integral é impossível. Mas é igualmente impossível deixar de assinalar passagens expressivas, sem o

43 Ibid, p. 407.

44 PAINTER, G. D., op. cit., p. 390. 
que a linguagem do "vício da inversão", em Proust, seria ininteligível em sua complexidade e genialidade. Proust diz: "Raça maldita, já que o que para ela é o ideal de beleza e alimento do desejo é também o objeto da vergonha e o medo da punição, e que ela é obrigada a viver até nos bancos dos tribunais onde vem como acusada e diante do Cristo, na mentira e no perjúrio, pois seu desejo seria de certa maneira insaciável pois só amando o homem que nada tem de mulher, o homem que não é 'homossexual', é apenas nele que ela pode saciar um desejo que ela não deveria por ele experimentar, se a necessidade de amor não fosse uma grande enganadora e não fizesse da mais infame 'bicha' uma aparência de homem (...), pois como os grandes criminosos ele é obrigado a esconder seu segredo daqueles que ele mais ama, temendo a dor de sua família, o desprezo de seus amigos, o castigo de seus pais; raça maldita, perseguida como Israel e como ele acabando no opróbio comum de uma abjeção não merecida, por assumir caracteres comuns, $o$ ar de uma raça (...) os traços físicos que no mais das vezes provocam repugnância, que algumas vezes são belos, corações de mulher, amantes e delicados, mas também uma natureza de mulher, desconfiada e perversa (...); excluídos da família, com quem não podem partilhar a inteira confiança, da pátria aos olhos de quem são criminosos não descobertos, de seus próprios semelhantes a quem inspiram a repulsa de reencontrar neles mesmos a advertência de que aquilo que eles acreditam ser um amor natural é uma loucura doentia (...) e, no entanto, corações amantes, excluídos da amizade porque os amigos poderiam suspeitar de outra coisa que não a amizade, quando experimentam por eles pura amizade, (...) objeto ora de um desconhecimento cego que só os ama desconhecendo o que são, ora de uma repulsa que os incrimina no que têm de mais puro, ora de uma curiosidade que busca explicálos e os compreende de maneira totalmente errada, elaborando a seu respeito uma psicologia de fantasia, que mesmo se acreditando imparcial ainda é tendenciosa e admite a priori, como estes juízes para quem um judeu era naturalmente um traidor, que um homossexual é facilmente um assassino; como Israel ainda buscando o que não é ele, o que não seria dele, mas experimentando, no entanto, uns pelos outros, sob a aparência das maledicências, das rivalidades, do desprezo do menos homossexual pelo mais homossexual (...) raça que põe seu orgulho em não ser uma raça, em não diferir do resto da humanidade, para que seu desejo não lhe apareça como uma doença, sua realização mesma como uma impossibilidade, seus prazeres como uma ilusão, suas características como uma tara (...) pois no fundo de todo homossexual há um anti-homossexual a quem não se pode fazer maior insulto que o de reconhecer-lhe os talentos, as virtudes, a inteligência, o coração, e, em suma, como a toda criatura humana, o direito ao amor sob a forma em que a natureza nos permitiu concehê-ln, se, 
entretanto, para permanecer na verdade, somos obrigados a confessar que esta forma é estranha, que estes homens não são semelhantes aos outros e repetindo sem cessar com uma satisfação irritante que Platão era homossexual, como os judeus que Jesus Cristo era judeu, sem compreender que não havia homossexuais na época em que o uso e o bom tom eram de viver com um rapaz, como hoje, de manter uma dançarina, onde Sócrates o homem mais moral que jamais existiu, fazia brincadeiras sobre dois jovens sentados um perto do outro, tão naturais quanto fazemos sobre um primo com uma prima que parecem enamorados e que são mais reveladores de um estado social que teorias que apenas lhes fosse pessoal, assim como não havia judeus antes da crucificação de Jesus Cristo (...); parte reprovada humanidade e no entanto membro essencial dela (...) etc." 45

No Cahier 7, novos acréscimos foram feitos a esta descrição: "Alguns solitários (...) outros gritando sua fé, ou, pelo menos, só encontrando prazer com seus correligionários, falando na língua, dizendo de bom grado palavras consagradas, fazendo gestos rituais, outros corretos, barbudos, burocratas empedernidos de seu vício, mantendo-se vis-à-vis dos jovens com uma reserva de moça de província, que acreditasse ser uma impudicícia dizer bom-dia, alguns maravilhosamente belos, espirituais, nobres, requisitados no mundo onde transitam com uma tristeza de anjos decaídos, olhando sem poder socia-las, mulheres se matarem por eles (...) etc." ${ }^{46}$

O fluxo é vertiginoso. Proust, de um só fôlego, confessou tudo o que ousara fantasiar sobre o sexo e que o Je mundano poderia dizer. O vocabulário que empregou para descrever o homoerotismo era uma imensa colagem do movimento de seus desejos, sob o olhar implacável do Faubourg e de Combray. Ou, dito de outra forma, era, de um lado, o homoerotismo de Proust, nome colado ao Faubourg Saint-Germain e à glória das letras francesas; de outro, o homoerotismo do pequeno Marcel, a quem a mãe, na hora da morte, prometera jamais abandonar. A historia, comumente, habituou-se a falar de um e de outro. Porém recalcou, como sempre, o que era incômodo relembrar: entre o pequeno Marcel e Proust, significante do tempo perdido, houve um outro Je, o Je Marcel Proust. Este, seguramente, interessa pouco à "arte" ou ao preconceito, mas interessa muito a todos que se recusam a fazer da vida uma existência sem arte.

Recuperando o tempo perdido e desperdiçado, Proust montou o processo íntimo de seu homoerotismo. Não tendo sobre a cabeça a Emenda Labouchère inglesa, como Wilde, ou o parágrafo 175 do Código Penal alemão, como

45 PROUST, M., op. cit., p. 520-522.

46 Ibid. 
Eulenburg, criou seu próprio tribunal e peças de acusação. Por que, pode-se perguntar, como Gide, Proust escolheu o lado soturno e melancólico do homoerotismo para ilustrar seus exemplos de "inversão"? Por receio da infâmia? Certamente. Isto não é só óbvio; é entendível e justificável. Proust conhecia bem a virulência do meio intelectual e mundano em que vivia. Quando publicou Les plaisirs et les jours, foi objeto de um ataque violento de Jean Lorrain (um dos modelos do barão de Charlus), que insinuou claramente o tipo de relação que existia entre ele e Lucien Daudet. ${ }^{47}$ Da mesma forma, estava ao par do episódio em que Henri de Régnier dissera, em público, que o conde Robert de Montesquiou (outro dos modelos de Charlus) "ficaria ainda melhor com um leque" ${ }^{48}$ ou da forma como a Sra. Holland tratava Leon Delafosse, protegido de Montesquiou e modelo do Morel, ou seja, chamando-o "Senhorita Delafosse."49

Fraco e apavorado, ele pressentia sua incapacidade de reagir a este tipo de agressão. Porém, na época da edição de Sodoma e Gomorra, o Faubourg era mais uma lembrança que uma realidade. Os farrapos aristocráticos de SaintGermain, tinham sido definitivamente jogados no lixo, depois da Primeira Guerra. Além do mais, Proust vivia enclausurado em seu quarto, mal saindo para encontrar-se com amigos e relações mais próximas, que preferia receber em casa. Fora isso, pode-se igualmente perguntar, o que lhe impediria de apresentar outras facetas do homoerotismo servindo-se de personagens fictícias? A dissimulação, neste caso, estaria preservada e continuaria a oferecer-lhe imunidade contra os eventuais detratores. Tudo isto era possível. Nada disto, entretanto, aconteceu porque, podemos supor, em Proust, a linguagem do vicio é, ao mesmo tempo, desejo de profanação.

Todos os invertidos de Sodoma e Gomorra são tipos desprezíveis. Vaugoubert é um covarde, emasculado pela mulher e pela preocupação com sua imagem de diplomata; Morel é um velhaco oportunista e obtuso, que vive como gigolô, às custas de Charlus; Jupien é um desfibrado, um subserviente, entremetteur de Charlus, seu antigo amante; e, finalmente, Charlus, figura central do romance, é um aristocrata arrogante, fútil, obeso, decaído, rancoroso e capaz das piores vinganças contra os que rejeitam seus avanços e dos piores ataques de pieguice histérica quando vítima dos sofrimentos do amor. Proust vai adiante. Não se contenta em mergulhar seus anti-heróis no "poço de Sodoma", feito de traições, canalhices e mágoas. Generaliza estes destinos pessoais, tornando-os tipos psíquicos representantes do que é a essência da inversão.

47 PAINTER, G. D., op. cit., p. 217.

48 Ibid, p. 219.

49 Ibid, p. 220. 
Pensando agir como um "herborista humano" ou um "botanista moral", ataca sem piedade o "vício" dentro de si e dos outros. Charlus é de uma sensibilidade paranóica, sempre prestes a "ver por toda parte, homens semelhantes a ele." Também exibia a "dureza e o desprezo que os invertidos" sentem por aqueles que os desejam, sem serem desejados." ${ }^{51}$ Quando diante de um outro invertido, sofria, não só por ver "uma imagem indesejável de si próprio", mas porque seu "instinto de conservação" o fazia ver num igual um possível concorrente. ${ }^{52}$ Neste caso, continuava, a raiva do invertido é ainda mais lancinante que a dos outros homens. ${ }^{53}$ Finalmente, aliada a todas estas características, estava a prática sado-masoquista que arrematava o perfil exemplar do invertido barão de Charlus.

Poucos são os momentos em que Proust usa expressões como "corajosos exilados de Sodoma"; "o vício, assim chamado por comodidade de linguagem"; "um gosto chamado vício", etc., ou refere-se aos invertidos como possuindo um especial "dom espiritual" para coisas sublimes e elevadas ${ }^{54}$ Mesmo assim, quando a virtude impunha-se à abominação, era para ser trazida de volta à inocência. Procurando dar conta do que havia de bom no homoerotismo, ou retirá-lo do terreno da maldiçào para colocá-lo na esfera do desejo, do gosto ou da preferência, Proust criou o mito da raça de Sodoma, no qual, novamente, a responsabilidade humana estava ausente. Neste mito, calcado no discurso de Aristófanes, em $O$ Banquete, de Platão, e na mitologia cristã das cidades da planície, o belo e o apreciável nos amores homoeróticos eram simplesmente a manifestação atávica de uma raça de seres que ansiavam inconscientemente por suas metades perdidas, das quais tinham sido privadas pela ira invejosa dos deuses. A virtude era de ninguém, porquanto de todos. Virtude burocrática e repetitiva, que obedecia sem desejar ou desejava apenas a obediência. O mito da raça de Sodoma, como aquele da inocência natural dos hommes-femmes, ou homens-flores, punha o desejo humano no céu das idéias, deixando impunes as cidades dos Guermantes e Combray.

Todavia, Marcel Proust, como dissemos, foi mais do que Proust e do que o pequeno Marcel. Em sua história de vida, nem a sexualidade foi sinônimo de homoerotismo, nem homoerotismo sinônimo do vício de Charlus. Na infância, adolescência, juventude e idade adulta, Proust apaixonou-se das mais diversas maneiras por homens e mulheres. $\mathrm{O}$ discutível fato de nunca ter tido relações

50 PROUST, M., op. cit., p. 311.

51 Ibid.

52 Ibid, pp. 311-312.

53 Ibid.

54 Ibid, pp. 15, 246, 343, 437. 
heteroeróticas é aqui de somenos importância. Juliette d'Artois, Marie de Benardaky, Jeanne Pouquet, Marie Finaly, Mme. Straus, Louiza de Mornand foram alguns de seus amores heteroeróticos. ${ }^{55}$ No que concerne ao homoerotismo, a discrepância entre o dito e o vivido é ainda maior, considerando-se que ele era a inclinação sexual predominante de Proust. Na juventude, ligara-se amorosamente a inúmeros amigos, embora sem relações sexuais físicas. De Edgar Aubert, dizia: "Enfim, encontrei o terno amigo de meus sonhos, que me escreve cartas." 56 De Robert de Flers, disse: "Alguém que é para mim tudo o que teria sido para X, se ele não fosse tão insensível. Refiro-me ao jovem, encantador, inteligente, amável e afetuoso Robert de Flers." ${ }^{, 57}$ Pouco depois, encontra o jovem inglês Willie Heath, com quem diz fazer planos para "viver cada vez mais juntos, num grupo seleto de homens e mulheres magnânimos, bem longe da estupidez, do vício e da malícia, para ficar ao abrigo de seus dardos vulgares." 58

Sem dúvida, a "inversão" de Marcel Proust tivera seus momentos de subida aos céus, em nada parecidos com o inferno de Sodoma. O teor de sua correspondência íntima e amorosa revela seu acesso à felicidade concebível, no código do amor romântico. Como qualquer apaixonado, homo ou heteroerótico, ele sentia e falava das delícias do amor, com as cores do romantismo época: tom confessional da emoção; exaltação do sentimentalismo; intimismo açucarado; idealização da parceria amorosa; sensiblerie; diatribes contra a insensatez do mundo, etc. Esta linguagem, cheia dos jargões mais triviais, era a linguagem reconhecida e aprovada como sendo a do amor virtuoso. Proust, portanto, sentira o gosto da virtude. No entanto, como qualquer outro indivíduo ocidental, de ontem ou de hoje, não podia aplicá-la publicamente ao homoerotismo, sob pena de incorrer em erro de uso. A virtude do amor só é moralmente correta e tolerada quando referida ao heteroerotismo. Ou seja, ele interiorizara o preconceito e, seguindo a regra, pronunciava vício onde experimentara virtude. Ao apaixonar-se, mais tarde, pelo músico Reynaldo Hahn, com quem viveu uma terna e prolongada relação amorosa, afirmou certa vez: "quero que você esteja sempre presente em meu romance, como um deus disfarçado que mortal nenhum pode reconhecer. ${ }^{, 59} \mathrm{Hahn}$ tornou-se, no romance, o heterossexual Henri de Réveillon. Decência oblige.

55 PAINTER, G. D., op. cit., pp. 49, 63, 93, 126, 352.

56 Ibid, p. 137.

57 Ibid.

58 Ibid, p. 132.

59 PROUST, M., op. cit., p. 214. 
As paixões por Lucien Daudet e, depois, pelo nobre Antoine Bibesco não fogem a regra. Ora, destes amores nenhum traço permaneceu na pintura homoerótica de Proust em seus romances. Entretanto, todos estes jovens, com exceção de Daudet, longe de serem cópias de Charlus, eram viris, corteses, despretensiosos, e Reynaldo Hahn, até os últimos dias de Proust, dedicou-lhe uma amizade desinteressada e generosa, absolutamente oposta à sórdida mesquinhez do barão. Da mesma forma, as relações posteriores de Proust com subalternos, como seu secretário particular Ulrich ou com seu chofer Agostinelli, mostram uma imagem do homoerotismo em nada assimilável ao perfil da "raça dos bichas" ou da "raça maldita" dos "hommes-femmes". Ulrich, que mantinha relações com Proust, e a quem era muito devotado, não negava $o$ prazer que tinha em manter relações sexuais com mulheres, o que incomodava pouco o patrão. ${ }^{60}$ Agostinelli, por quem Proust foi extremamente apaixonado, também mantinha regularmente relações heteroeróticas e era casado com Anna, de quem Proust sentia muitos ciúmes. ${ }^{61}$

O homoerotismo de Marcel Proust foi, assim, uma multiplicidade de relações afetivas e sexuais polimorfas, que o Narrador congelou e dissecou a partir de um só ângulo e com um só bisturi. O ângulo feliz e pacificado de sua sexualidade foi expurgado do tempo recuperado, dando vez ao vício e à profanação. Escolhendo o barão de Charlus como o exemplo de invertido, Proust quis fazer ver aos outros que grand monde e bas-fond não se distinguem quando o assunto é amor. Chez les Guermantes, como dizia Brichot, "as pessoas passam o tempo a considerar seus umbigos como se fossem o centro do mundo." ${ }^{62} \mathrm{Ali}$, a grande "virtude" era a reputação; portanto, mesmo o mal era bem-vindo, desde que rendesse dividendos. Por outro lado, "as pessoas de Combray podiam achar que tinham bom coração, sensibilidade, e adquirir as mais belas teorias sobre a igualdade humana; minha mãe, quando um valet de chambre se emancipava, (...) manifestava a respeito destas usurpações o mesmo descontentamento que explode nas Memórias de Saint-Simon, toda vez que um seigneur, sem direito, opunha a pretexto de tomar a qualidade de Alteza em um ato autêntico, ou de não conferir aos duques o que lhes é devido e do que, pouco a pouco, se isenta. Havia um espírito de Combray tão refratário, que seriam necessários séculos de bondade (aquela de minha mãe era infinita), de teorias igualitárias, para conseguir dissolvê-lo." 63 Isto é, também, a moralidade burguesa e materna era insensível às "intermitências do coração".

60 PAINTER, G.D., op. cit., p. 416.

61 Ibid, p. 551.

62 PROUST, M., op. cit., p. 346. 
Depois da morte da mãe a docilidade virou rebelião. Combray e o Faubourg associaram-se num só grande outro opressor, bem distante do severo, mas protetor, Deus de Gide. Proust disse, certa vez, falando de Charlus: "O mais perigoso de todos os segredos é aquele da falta, ela mesma, no espírito do culpado." "6ste era o segredo a que se referia quando escrevia à Sra. Straus sobre as "verdades psicológicas, humanas ou emocionais" de suas desgraças. Este sentimento de falta diante do mundo e da mãe era de uma enormidade proporcional à impiedade que Proust, em seu infantilismo afetivo e em sua sagacidade intelectual, via na moralidade aristocrático-burguesa que $o$ asfixiava. O "vício" do seu homoerotismo era do tamanho de ogro do Faubourg e de Combray. Preso a dois mundos sem misericórdia, transfigurou a fraqueza em ódio e a idolatria em profanação. Proust profanou o mundo dos Guermantes com o vício de Charlus, assim como profanou o mundo familiar e burguês com o vício de Gomorra; de novo, dissimuladamente, acertava contas, em meio a culpas e tormentos com seus amados perseguidores.

Em 1917, começa a relacionar-se com Albert Le Cuziat, conhecido prostituto do grand monde parisiense, a quem ajuda a montar um bordel masculino, com dinheiro, "cadeiras, sofás, e tapetes" que pertenciam aos falecidos pais. ${ }^{65}$ Quando no romance, o "Narrador presenteia a dona do bordel de Bloch com as cadeiras e o sofá da tia Leonie, é assaltado pelo remorso" e diz que é como se "tivesse contribuído para a violação do corpo de uma mulher morta" (...), "porque os móveis pareciam estar vivos e me fazer súplicas, como os objetos aparentemente inanimados das Mil e uma noites, onde almas humanas estão aprisionadas, sofrendo martírios e implorando a libertação." ${ }^{66} \mathrm{Em}$ Montjouvain, o Narrador, através da janela, vê a Srta. Vinteuil incitar sua parceira a cuspir no retrato do pai e a chamá-lo de "velho macaco", para excitar-se sexualmente. ${ }^{67}$

Ritual de expiação e profanação, o "vício do homoerotismo é o vício de um Je que do outro fez o senhor e de si mesmo, o escravo. Esta servidão, nutrida por amor e ódio, era simultaneamente dom e recusa. Proust deu ao Faubourg e a Combray a parte maldita de sua sexualidade, guardando para si a beleza das lembranças eróticas, preservadas do desgaste pela dissimulação. Seus amores felizes vestiram a máscara heteroerótica para se liberarem eternamente da

63 PROUST, op. cit., p. 415.

64 Ibid, p. 113.

65 PAINTER, G.D., op. cit., p. 607-608.

66 PAINTER, G. D., op. cit., p. 671.

67 Ibid, pp. 49 e 329. 
conspurcação. Ao vencedor, as batatas; aos vencidos, a recordação intocável dos prazeres e os dias.

Proust, como artista, de sua arte fez simulacro de uma vie donnée; de uma daquelas vidas "que não guardam nada para si, nem um só minuto, nem um só prazer" já que "tudo, inteiramente tudo, é um sacrifício pelos outros." ${ }^{68}$ Como homem, fez de sua vida uma paródia do que a tolice mundana recomendava encenar. Ganhou a consagração da arte e qualquer coisa da vida, mas não logrou fazer de sua vida uma obra de arte. Talvez, porque este seja o sonho impossível do desejo humano. Proust, em todo caso, conhecia na carne o desencontro entre vida e amor. As coisas que esperamos nunca chegam a tempo. Ou, o que dá no mesmo, quando chegam, o tempo passou.

Perto da morte, dizia à fiel Celeste Albaret, sobre o médico chamado para atendê-lo: "Como tudo o mais, chegará muito tarde."

\section{RESUMO}

\section{A Inocência e o Vício: Du Cotê de Chez Proust}

Este trabalho trata da criação da linguagem descritiva do homossexualismo masculino em Sodoma e Gomorra de Proust. Defende-se a tese de que Proust definiu a pretensa natureza do homoerotismo servindo-se das categorias da inocência e do vício, implícitas na tessitura do romance. Ambas as categorias estão fortemente marcadas pelas ideologias evolucionistas e instintivas do século XIX e desenham um perfil moral do homoerotismo com base em uma ética predominantemente naturalista, preconceituosa e estigmatizante. Ao lado desta constatação, o estudo mostra também a articulação da invenção teórico-estética de Proust sobre o homoerotismo com a realidade histórico-social de seu tempo e a extraordinária capacidade do autor para redescrever a idéia de sujeito ou subjetividade, como um entrecruzamento de crenças e desejos contingentes.

68 Ibid, p. 242. 


\begin{abstract}
Innocence and Vice: Du Côté de Chez Proust

The article deals with Proust's creation of language descriptive of masculine homosexuality in his novel Sodom and Gomorrah. The thesis is that Proust used the categories of innocence and vice, implicit in the contexture of this novel, to define the would-be nature of homoerotism. Both of these categories are heavily branded by the nineteenth century's evolutionist and instinctive ideologies and draw a moral profile of homoerotism grounded in a predominantly naturalist, prejudiced, and stigmatizing ethic. The article also shows the articulation of Proust's theoretical-aesthetic invention regarding homoerotism with the historical-social reality of his time and points to the author's extraordinary ability to redescribe the idea of subject or subjectivity as a blending of contingent beliefs and desires.
\end{abstract}

\title{
RESUME
}

\section{L’Innocence et le Vice: du côté de chez Proust}

Ce travail a pour but d'analyser, dans Sodome et Gomorre de Proust, la création d'un langage servant à décrire l'homosexualisme masculin. Pour définir la soi-disante nature de l'homoérotisme, Proust s'est servi, selon l'auteur, de deux catégories qui sont implicites dans le tissu même du roman: l'Innocence et le Vice. Aussi bien l'une que l'autre sont fortement marquées par les idéologies évolutionnistes et instinctivistes propres au XIXème siècle. Elles dessinent un profil moral de l'homoérotisme basé sur une éthique essentiellement naturaliste, empreinte de préjugés et stigmatisante. Mais l'étude ne se limite pas a rendre compte de cette constatation. Elle révèle aussi comment l'invention théorique et esthétique de Proust en ce qui concerne l'homoérotisme s'articule avec la réalité historique et sociale de son époque. Elle montre enfin l'extraordinaire capacité dont fait preuve cet auteur quand il redécrit l'idée de sujet ou de subjectivité comme un entrecroisement de croyances et de désirs contingents. 
